\title{
UJI BEBERAPA KONSENTRASI EKSTRAK BIJI PINANG (Areca catechu L.) UNTUK MENGENDALIKAN HAMA ULAT JENGKAL (Chrysodeixis chalcites Esper) PADA TANAMAN KEDELAI (Glycine max L.)
}

\section{Test of Areca Nuts (Areca catechu L.) Extract Concentrations to Control Esper Pest (Chrysodeixis chalcites) on Soybean Plants (Glycine max L.)}

\author{
Desita Salbiah, Rusli Rustam, Forti Senorita Daeli \\ Agrotechnology Departement \\ Faculty of Agriculture, Riau University \\ Email: sdesita@yahoo.com \\ [Diterima Juni 2019; Disetujui Agustus 2019]
}

\begin{abstract}
Chrysodeixis chalcites Esper is the main pests in soybean plants cultivation that can cause damage up to $90 \%$. One of controlling was done by using areca nuts (Areca catechu L.) which has a potential as a botanical insecticide. This study aimed to obtain effective concentrations of areca nuts extract to control Chrysodeixis chalcites Esper pests on soybean plants (Glycine max L.). This research was conducted at the Laboratory of Plant Pest and Experimental Farm, Faculty of Agriculture, Riau University, Pekanbaru from August to November 2018. The study was conducted experimentally using a completely randomized design (CRD), which consisted of five treatments and four replications, namely: the concentration areca nuts extract 0 g.l-1 water, 20 g.l-1 water, 40 g.l-1 water, 60 g.l-1 water, and 80 g.l-1 water. The results showed that the concentration of 80 g.l-1 of water was an effective concentration to control Chrysodeixis chalcites pest with an initial death time of 14 hours, lethal time 5029.25 hours after application, and total mortality of $87.50 \%$.
\end{abstract}

Keywords: Soybean plants, Golden twin spot, Botanical insecticides, Areca nuts extract

\begin{abstract}
ABSTRAK
Ulat jengkal (Chrysodeixis chalcites Esper) merupakan hama utama dalam budidaya tanaman kedelai yang dapat menyebabkan kerusakan hingga 90\%. Pengendalian yang dapat dilakukan yaitu dengan memanfaatkan tanaman pinang (Areca catechu) yang berpotensi sebagai pestisida (insektisida) nabati. Penelitian ini bertujuan untuk memperoleh konsentrasi ekstrak biji pinang yang efektif untuk mengendalikan hama ulat jengkal (Chrysodeixis chalcites Esper) pada tanaman kedelai (Glycine max L.). Penelitian dilaksanakan di Laboratorium Hama Tumbuhan dan Kebun Percobaan, Fakultas Pertanian, Universitas Riau, Pekanbaru dari Agustus hingga November 2018. Penelitian dilaksanakan secara eksperimen dengan menggunakan rancangan acak lengkap (RAL), yang terdiri dari lima perlakuan dan empat kali ulangan yaitu: konsentrasi ekstrak biji pinang 0 g. $1^{-1}$ air, 20 g. $l^{-1}$ air, 40 g..$^{-1}$ air, 60 g. $1^{-1}$ air dan 80 g..$^{-1}$ air. Hasil penelitian menunjukan bahwa konsentrasi 80 g. $1^{-1}$ air merupakan konsentrasi yang efektif terhadap hama ulat jengkal dengan waktu awal kematian 14 jam, lethal time 5029,25 jam setelah aplikasi dan mortalitas total $87,50 \%$.
\end{abstract}

Kata kunci : Tanaman kedelai, Ulat jengkal, Pestisida nabati, Ekstrak biji pinang

\section{PENDAHULUAN}

Permasalahan utama yang dapat mengakibatkan penurunan produksi kedelai di Indonesia khususnya di Provinsi Riau yaitu adanya serangan hama. Hama utama yang menyerang tanaman kedelai adalah ulat jengkal (Chrysodeixis chalcites E.). Ulat jengkal menyerang daun tanaman muda maupun daun tanaman tua, sehingga mempengaruhi pertumbuhan dan perkembangan tanaman kedelai (Marwoto dan Suharsono, 2008).

Pengendalian yang dilakukan untuk menekan populasi $C$. chalcites di lapangan pada umumnya dengan penggunaan insektisida kimia sintentik. Penggunaan insektisida sintentik secara terus menerus dapat menimbulkan dampak negatif seperti efek residu pada hasil pertanian yang kurang baik bagi kesehatan, resistensi hama, resurgensi 
hama, timbulnya hama sekunder, matinya musuh alami dan pencemaran lingkungan (Pracaya, 2007).

Insektisida nabati merupakan alternatif pengendalian yang bisa diterapkan karena aman dan ramah lingkungan dalam pengendalian organisme pengganggu tanaman (OPT). Salah satu tumbuhan yang berpotensi sebagai insektisida nabati yang dapat mengendalikan hama $C$. chalcites adalah biji pinang (Areca catechu).

Pemanfaatan ekstrak biji pinang telah dilakukan oleh Dewi (2017) menunjukan konsentrasi ekstrak biji pinang 50 g.l-1 air untuk mengendalikan larva $H$. armigera mencapai $90 \%$ dengan waktu awal kematian 30 jam setelah aplikasi.

Penelitian bertujuan untuk mendapatkan konsentrasi ekstrak biji pinang (Areca catechu L.) yang efektif terhadap hama ulat jengkal (Chrysodeixis chalcites Esper) pada tanaman kedelai (Glycine max L.).

\section{METODOLOGI}

Penelitian telah dilaksanakan di Laboratorium Hama Tumbuhan dan di Rumah Kasa Fakultas Pertanian, Universitas Riau, Pekanbaru. Penelitian telah dilaksanakan dari bulan Agustus hingga November 2018.

Bahan yang digunakan adalah ulat jengkal instar tiga, benih kedelai varietas Anjasmoro, ekstrak biji pinang, tanah lapisan atas, aquades steril, dan sabun krim.

Alat yang digunakan antara lain pisau, cangkul, parang, polybag $30 \times 40 \mathrm{~cm}$, pupuk kandang ayam, shading net, paku, kayu, tali plastik, stoples ukuran $10 \times 15 \mathrm{~cm}$, plastik, pinset, gelas ukur $100 \mathrm{ml}$, timbangan analitik, blender, ayakan, kain kasa, batang pengaduk, tisu gulung, erlenmeyer $1000 \mathrm{ml}$, hand sprayer $1000 \mathrm{ml}$, termohygrometer, kamera, kertas label dan alat tulis.

Penelitian dilaksanakan secara eksperimen dengan menggunakan rancangan acak lengkap (RAL), yang terdiri dari 5 perlakuan dan 4 kali ulangan sehingga diperoleh 20 unit percobaan. Setiap unit percobaan diinfestasikan sebanyak 10 ekor ulat jengkal instar tiga. Perlakuan yang diberikan pada masing-masing unit percobaan adalah konsentrasi ekstrak biji pinang sebagai berikut: $\mathrm{P} 0=0 \mathrm{~g}$ ekstrak biji pinang $1-1$ air $\mathrm{P} 1=20 \mathrm{~g}$ ekstrak biji pinang $1-1$ air $\mathrm{P} 2=40 \mathrm{~g}$ ekstrak biji pinang $1-1$ air $\mathrm{P} 3=60 \mathrm{~g}$ ekstrak biji pinang $1-1$ air P4= 80 g ekstrak biji pinang 1-1 air. Hasil analisis sidik ragam yang berbeda nyata diuji lanjut dengan BNT pada taraf 5\%.

Parameter pengamatan yang diamati yaitu perubahan tingkah laku dan morfologi, waktu awal kematian, lethal time 50 (LT50), mortalitas harian dan mortalitas total.

\section{HASIL DAN PEMBAHASAN}

\section{Perubahan tingkah laku dan morfologi ulat jengkal}

Hasil pengamatan perubahan tingkah laku ulat jengkal terjadi 10 jam ditunjukkan dengan menurunnya aktifitas gerak menjadi lamban, nafsu makan menurun, sehingga tubuh menjadi lemah dan akhirnya mati setelah diberi perlakuan beberapa konsentrasi ekstrak biji pinang. Menurut Matsumura (1985) dalam Nursal et al. (1997) bahwa senyawa toksin yang terkandung dalam ekstrak biji buah pinang adalah senyawa arekolin yang dapat menyebabkan aktivitas makan ulat terganggu, menurunnya aktivitas metabolisme tubuh dan pencernaan sehingga tubuh ulat mengeluarkan cairan dan menjadi kaku.

Perubahan morfologi ditunjukkan dengan perubahan warna tubuh. Perubahan warna yang terjadi setelah perlakuan ekstrak biji pinang semula berwarna hijau muda perlahan-lahan berubah menjadi hijau kekuningan, kemudian menjadi kuning kecoklatan dan akhirnya berubah menjadi cokelat kehitaman.

Perubahan warna yang terjadi setelah perlakuan ekstrak biji pinang diduga memperlihatkan gejala melanisasi yang terjadi pada tubuh ulat jengkal. Dono et al. (2006) menyatakan bahwa dalam proses melanisasi selalu melibatkan fenoloksidase yang dicirikan dengan warna cokelat dan hitam. Tubuh ulat jengkal menjadi kaku, tidak bergerak, mengeluarkan cairan dari tubuh, kemudian mengeras dan akhirnya tubuh menjadi kering yang menandakan ulat jengkal tersebut telah mati. Ulat jengkal yang mati akibat pemberian ekstrak biji pinang dapat dilihat pada Gambar 1. 


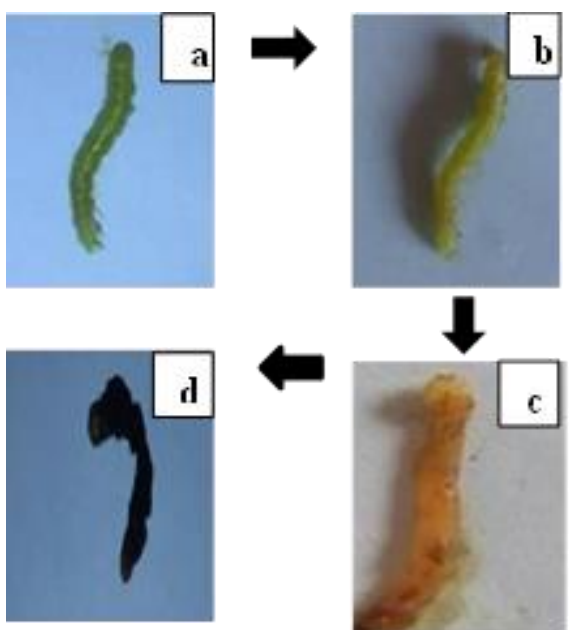

Gambar 1. Perubahan morfologi ulat jengkal setelah aplikasi ekstrak biji pinang.

Keterangan: (a) ulat jengkal sebelum aplikasi, (b) 27 jam setelah aplikasi, (c) 46 jam setelah aplikasi, (d) 68 jam setelah aplikasi.

Sumber: (Dokumentasi penelitian, 2018).

\section{Waktu awal kematian (jam)}

Hasil pengamatan awal kematian ulat jengkal setelah dianalisis menggunakan sidik ragam menunjukkan bahwa perlakuan dari beberapa konsentrasi ekstrak biji pinang (Areca catechu L.) memberikan pengaruh nyata terhadap waktu awal kematian ulat jengkal, hasil uji lanjut BNT pada taraf 5\% dapat dilihat pada Tabel 1.

Tabel 1. Rata-rata awal kematian ulat jengkal dengan perlakuan beberapa konsentrasi ekstrak biji pinang (jam)

\begin{tabular}{cc}
\hline $\begin{array}{c}\text { Konsentrasi ekstrak } \\
\text { biji pinang }\left(\mathrm{g} . \mathrm{l}^{-1}\right. \\
\text { air) }\end{array}$ & $\begin{array}{c}\text { Rata-rata waktu awal } \\
\text { kematian ulat jengkal } \\
\text { (jam) }\end{array}$ \\
\hline 0 & $72 \mathrm{~d}$ \\
20 & $23 \mathrm{c}$ \\
40 & $22 \mathrm{c}$ \\
60 & $18 \mathrm{~b}$ \\
80 & $14 \mathrm{a}$ \\
\hline $\mathrm{KK}=2,84 \%$ &
\end{tabular}

Angka-angka yang diikuti oleh huruf kecil yang berbeda memberikan perbedaan yang nyata menurut uji lanjut BNT pada taraf $5 \%$.

Tabel 1 menunjukkan bahwa pemberian konsentrasi ekstrak biji pinang 80 g.l-1 air menyebabkan waktu awal kematian ulat jengkal tercepat yaitu 14 jam setelah aplikasi. Konsentrasi 80 g.l-1 air berbeda nyata dengan semua perlakuan, hal ini disebabkan karena konsentrasi 80 g.l-1 air lebih tinggi dibandingkan dengan konsentrasi lainnya. Hal ini diduga senyawa aktif arekolin yang terdapat di dalam ekstrak biji pinang masuk ke dalam tubuh ulat jengkal sebagai racun kontak dan racun perut serta bekerja secara cepat sebagai racun saraf.

Menurut Dewi (2017) bahwa arekolin merupakan senyawa yang dapat bersifat insektisida yang masuk sebagai racun kontak dan racun perut. Racun kontak masuk melalui lubang-lubang alami dari tubuh ulat jengkal sedangkan racun perut masuk melalui proses makan. Senyawa arekolin yang telah masuk ke dalam tubuh serangga, senyawa tersebut bekerja sebagai racun saraf sehingga dapat menghambat respirasi sel dan pernafasan terganggu sehingga menyebabkan kematian pada serangga.

Konsentrasi ekstrak biji pinang 60 g.l1 air berbeda nyata dengan konsentrasi 40 g.l-1 air dan konsentrasi 20 g.l-1 air. Hal ini menunjukan bahwa dengan peningkatanan konsentrasi 40 g.l-1 air menjadi 60 g.l-1 air telah memberikan pengaruh yang nyata. Hal ini diduga kandungan senyawa arekolin pada konsentrasi 60 g.l-1 air sudah bekerja secara maksimal sehingga waktu yang dibutuhkan lebih cepat untuk mematikan ulat jengkal karena senyawa arekolin telah banyak masuk ke dalam tubuh ulat jengkal. Sesuai dengan pendapat Nursal et al. (1997) bahwa pemberian konsentrasi ekstrak yang lebih tinggi maka pengaruh yang ditimbulkan pada serangga juga tinggi, disamping itu efektifnya suatu pestisida nabati sangat ditentukan oleh besarnya konsentrasi yang diberikan.

Konsentrasi ekstrak biji pinang 40 g.l1 air berbeda tidak nyata dengan konsentrasi 20 g.l-1 air. Hal ini diduga karena senyawa arekolin tersebut belum memberikan pengaruh yang nyata terhadap waktu awal kematian. Hal ini diduga karena perlakuan keduanya memberikan respon yang sama untuk mematikan ulat jengkal. Menurut Prijono (2002) reaksi pestisida nabati lambat sehingga waktu yang dibutuhkan untuk mematikan serangga uji juga lambat. Konsentrasi ekstrak biji pinang 0 g.l-1 air tidak ada ulat jengkal yang mati sampai akhir pengamatan. Hal ini disebabkan karena tidak terdapat senyawa racun yang dapat menyebabkan kematian pada ulat jengkal.

Perbedaan waktu awal kematian ini diduga karena konsentrasi yang diberikan pada setiap perlakuan berbeda-beda, semakin tinggi konsentrasi yang diberikan maka senyawa 
arekolin yang terdapat pada ekstrak biji pinang semakin tinggi yang mengakibatkan semakin banyak pula senyawa yang masuk pada tubuh ulat jengkal.

Senyawa arekolin yang terdapat dalam biji pinang masuk sebagai racun kontak dan racun perut. Racun kontak masuk melalui lubang-lubang alami dari tubuh ulat jengkal, sedangkan racun perut masuk melalui proses makan. Setelah racun masuk ke dalam tubuh ulat, racun akan bekerja racun saraf sehingga aktifitas ulat terganggu dan menyebabkan kematian. Hal ini menunjukkan bahwa senyawa arekolin yang terkandung dalam ekstrak biji pinang bersifat sebagai racun saraf sehingga mengganggu sistem pencernaan dalam tubuh ulat jengkal. Sistem saraf ulat jengkal yang terganggu akan mempengaruhi perilaku ulat dan menghambat reseptor perasa pada daerah mulut sehingga tidak mampu mengenali makanan dan akhirnya mati ( $\mathrm{Lu}$, 1989). Sastrodiharjo (1984) menyatakan bahwa mortalitas serangga disebabkan racun yang terbawa melalui makanan dibawa ke organ pencernaan untuk di cerna dalam saluran tengah dan ditranslokasikan ke pusat sasaran insektisida, sehingga menyebabkan terganggunya aktifitas serangga uji.

\section{Lethal Time (LT50) (jam)}

Hasil pengamatan untuk mematikan ulat jengkal sebanyak 50\% (Lethal Time 50) setelah dianalisis menggunakan sidik ragam menunjukkan bahwa perlakuan konsentrasi ekstrak biji pinang (Areca catechu L.) memberikan pengaruh nyata terhadap waktu yang dibutuhkan ekstrak biji pinang untuk mematikan ulat jengkal sebanyak 50\% Hasil uji lanjut BNT pada taraf 5\% dapat dilihat pada Tabel 2.

Tabel 2. Rata-rata Lethal Time 50 ulat jengkal dengan perlakuan beberapa konsentrasi ekstrak biji pinang (jam)

\begin{tabular}{cc}
\hline $\begin{array}{c}\text { Konsentrasi ekstrak } \\
\text { biji pinang } \\
\left.\text { ( g.1 }{ }^{-1} \text { air }\right)\end{array}$ & $\begin{array}{c}\text { Rata-rata lethal time } 50 \\
\text { ulat jengkal (jam) }\end{array}$ \\
\hline 0 & $72,00 \mathrm{~d}$ \\
20 & $53,25 \mathrm{c}$ \\
40 & $40,75 \mathrm{~b}$ \\
60 & $37,25 \mathrm{~b}$ \\
80 & $29,25 \mathrm{a}$ \\
\hline
\end{tabular}

$\mathrm{KK}=4,44 \%$

Angka-angka yang diikuti oleh huruf kecil yang berbeda memberikan perbedaan yang nyata menurut uji lanjut BNT pada taraf $5 \%$.
Tabel 2 menunjukkan bahwa pemberian konsentrasi ekstrak biji pinang 80 g.l-1 air menyebabkan waktu tercepat dalam mematikan 50\% ulat jengkal yaitu 29,25 jam setelah aplikasi. Konsentrasi 80 g.l-1 air berbeda nyata dengan semua perlakuan. Hal ini berkaitan pada Tabel 1 bahwa konsentrasi 80 g.l-1 air menunjukkan awal kematian ulat jegkal paling cepat shingga mengakibatkan LT50 juga cepat. Hal ini diduga semakin banyak senyawa aktif yang telah terakumulasi dalam tubuh ulat jengkal sehingga mempercepat kematian $50 \%$ ulat jengkal. Sesuai dengan pendapat Rusdy et al. (1998), menyatakan bahwa senyawa yang terkandung dalam konsentrasi ekstrak biji pinang yang tinggi maka pengaruh yang ditimbulkan terhadap kematian serangga uji semakin cepat.

Konsentrasi ekstrak biji pinang 60 g.l1 air berbeda tidak nyata dengan konsentrasi 40 g.l-1 air. Hal ini diduga karena perlakuan konsentrasi 60 g.l-1 air senyawa arekolin belum bekerja secara maksimal di dalam tubuh ulat jengkal, sehingga memiliki respon yang sama untuk mematikan 50\% ulat jengkal dengan perlakuan 40 g.l-1 air. Hal ini disebabkan adanya respon ulat jengkal yang relatif sama terhadap peningkatan konsentrasi dan sifat racun saraf yang dimiliki ekstrak biji pinang tersebut, sehingga kepekatan setiap konsentrasi belum mampu memberikan pengaruh nyata terhadap LT50 ulat jengkal tersebut. Prijono (2002) menyatakan bahwa reaksi pestisida nabati lambat sehingga waktu yang dibutuhkan untuk mematikan ulat jengkal juga lambat.

Konsentrasi ekstrak biji pinang 20 g.l1 air menunjukkkan pengaruh yang berbeda nyata dengan konsentrasi 40 g.l-1 air. Hal ini berbeda pada waktu awal kematian (Tabel 1) dimana konsentrasi 20 g.l-1 air dan 40 g.l-1 air menunjukkan hasil yang berbeda tidak nyata. Hal ini dikarenakan konsentrasi yang rendah menyebabkan bahan aktif arekolin bekerja secara lambat. Menurut Harborne (1979) dalam Nursal et al. (1997) pada pemberian suatu bahan pestisida nabati dengan konsentrasi rendah mortalitas yang ditimbulkan juga rendah. Pada perlakuan tanpa pemberian ekstrak biji pinang 0 g.l-1 air tidak ada ulat yang mati sampai akhir pengamatan selama 72 jam. Hal ini menunjukkan bahwa masing-masing perlakuan berpotensi untuk membunuh ulat jengkal sebanyak 50\% dari 
total ulat jengkal walaupun dengan waktu yang berbeda-beda.

Senyawa arekolin dapat mengganggu aktifitas makan, racun yang terkandung dalam ekstrak biji pinang juga dapat terserap melalui dinding tubuh ulat jengkal, dalam hal ini ekstrak biji pinang masuk sebagai racun kontak. Mekanisme kerja racun kontak adaah insektisida masuk ke dalam tubuh seranga melalui kulit, dinding tubuh, lubang alami pada tubuh serangga (Ardiansyah et al., 2001).

Senyawa arekolin selain masuk sebagai racun kontak juga masuk sebagai racun perut melalui alat mulut ulat jengkal, emudian masuk melalui kerongkongan, lalu masuk ke saluran pencernaan yang akan menyebabkan terganggunya aktivitas makan ulat jengkal. Menurunnya aktivfitas makan secara perlahanlahan dan akan menyebabkan kematian. Hal ini sesuai dengan pernyataan Permana (2013) menyatakan senyawa kimia arekolin masuk ketubuh serangga uji sebagai racun perut, senyawa tersebut merusak sistem saraf, terganggunya sistem saraf pada tubuh serangga dan mempengaruhi aktifitas metabolisme sehingga menyebabkan terjadinya penurunan aktifits gerak dan akhirnya serangga akan mati.

\section{Mortalitas harian (\%)}

Hasil pengamatan mortalitas harian terhadap ulat jengkal dengan perlakuan konsentrasi ekstrak biji pinang yang berbeda menunjukkan pengaruh terhadap kematian ulat jengkal. Persentase mortalitas harian ulat jengkal dapat dilihat pada Gambar 2.

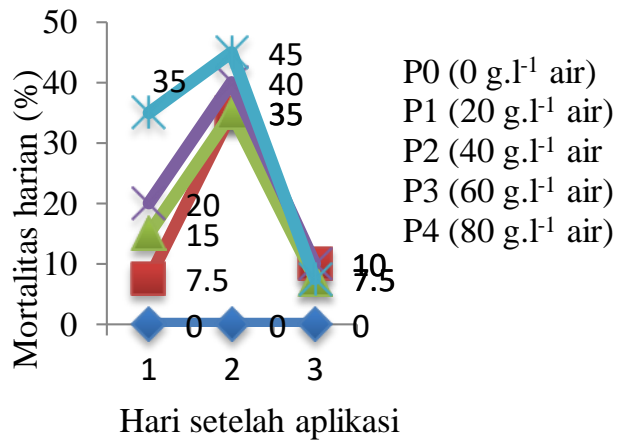

Gambar 2. Fluktuasi Mortalitas Harian Ulat Jengkal Setelah Aplikasi Beberapa Konsentrasi Ekstrak Biji Pinang

Gambar 2 menunjukkan bahwa fluktuasi mortalitas harian ulat jengkal pada hari pertama semua perlakuan sudah menyebabkan kematian dengan kisaran 7,5$35 \%$. Puncak mortalitas harian ulat jengkal terjadi pada hari kedua dengan kisaran 35$45 \%$. Mortalitas harian pada hari kedua terlihat bahwa perlakuan konsentrasi 80 g.l-1 air merupakan konsentrasi yang mencapai puncak mortalitas dengan persentase $45 \%$. Hal ini diduga karena konsentrasi tersebut merupakan konsentrasi tertinggi yang mengandung senyawa arekolin yang tinggi, sehingga daya racunnya juga tinggi dan semakin cepat pula daya bunuh terhadap ulat jengkal. Hal ini sesuai dengan pendapat Sari (2013) bahwa peningkatan konsentrasi berbanding lurus dengan peningkatan bahan racun tersebut, sehingga daya bunuh semakin tinggi. Senyawa arekolin ini masuk ke dalam sistem saraf dan akan merusak sel saraf sehingga organ otot serta organ lainnya akan terhambat dan akhirnya akan menyebabkan kematian (Asmawi, 1986 dalam Gassa et al., 2008).

Hari ke tiga pengamatan menunjukkan persentase kematian ulat jengkal mengalami penurunan pada setiap perlakuan dengan persentase kematian adalah berturut-turut konsentrasi 80 g.l-1 air sebesar 7,5\%, konsnentrasi 60 g.l-1 air sebesar 10\%, konsentrasi 40 g.l-1 air sebesar 7,5\% dan konsentrasi 20 g.l-1 air sebesar $10 \%$. Hal ini diduga karena jumlah ulat jengkal pada hari pertama dan hari kedua telah banyak yang mati, kemudian diduga senyawa arekolin yang terdapat pada biji pinang telah menurun. Hal ini sesuai dengan pendapat Sastrosiswojo (2002) menyatakan bahwa pestisida nabati cepat terurai dan residunya mudah hilang, hal ini disebabkan senyawa kimia yang terdapat dalam pestisida nabati mudah terdegradasi oleh lingkungan dan sinar matahari.

\section{Mortalitas total (\%)}

Hasil pengamatan persentase mortalitas total ulat jengkal setelah dianalisis menggunakan sidik ragam menunjukkan bahwa perlakuan konsentrasi ekstrak biji pinang memberikan pengaruh nyata terhadap persentase mortalitas total ulat jengkal dan hasil uji lanjut BNT pada taraf 5\% dapat dilihat pada Tabel 3.

Tabel 3 menunjukkan bahwa mortalitas tertinggi terdapat pada pelakuan konsentrasi 80 g.l-1 air dengan mortalitas total sebesar $87,50 \%$. Hal ini berkaitan dengan Tabel 1 dan Tabel 2 yaitu dengan waktu awal kematian ulat jengkal selama 14 jam dan LT50 ulat jengkal dengan waktu 29,25 jam 
dibandingkan dengan perlakuan lainnya. Hal ini disebabkan karena semakin tinggi konsentrasi biji pinang maka semakin banyak senyawa arekolin yang dihasilkan, semakin banyak ekstrak biji pinang yang masuk ke dalam tubuh ulat jengkal akan menyebabkan semakin tinggi kematian ulat jengkal. Pernyataan ini didukung oleh Mulyana (2002) bahwa pemberian dengan konsentrasi yang tinggi menyebabkan serangga cepat mengalami kematain hal ini disebabkan banyaknya senyawa yang masuk ke dalam tubuh ulat.

Tabel 3. Rata-rata mortalitas total ulat jengkal dengan perlakuan beberapa konsentrasi ekstrak biji pinang (\%)

\begin{tabular}{cc}
\hline $\begin{array}{c}\text { Konsentrasi ekstrak } \\
\text { biji pinang } \\
\left.\text { (g. } \text { - }^{-1} \text { air }\right)\end{array}$ & $\begin{array}{c}\text { Rata-rata mortalitas } \\
\text { total ulat jegkal }(\%)\end{array}$ \\
0 & $0,00 \mathrm{~d}$ \\
20 & $47,50 \mathrm{c}$ \\
40 & $60,00 \mathrm{~b}$ \\
60 & $62,50 \mathrm{~b}$ \\
80 & $87,50 \mathrm{a}$ \\
\hline $\mathrm{KK} \quad=8.87$ & \\
\hline
\end{tabular}

Angka-angka yang diikuti oleh huruf kecil yang berbeda memberikan perbedaan yang nyata menurut uji lanjut BNT pada taraf $5 \%$. Setelah ditransformasi dengan formula $\sqrt{y}$.

Hasil pengamatan mortalitas total menunjukkan konsentrasi 80 g.l-1 air merupakan konsentrasi yang efektif dimana dapat menyebabkan mortalitas total ulat jengkal sebesar $87,50 \%$. Hal ini sesuai dengan pendapat Dadang dan Prijono (2008) yang menyatakan bahwa ekstrak pestisida nabati dikatakan efektif apabila perlakuan dengan ekstrak tersebut dapat mengakibatkan tingkat kematian lebih besar dari $80 \%$.

Konsentrasi ekstrak biji pinang 60 g.l1 air menunjukkan persentase mortalitas total ulat jengkal sebesar $62,50 \%$ berbeda tidak nyata dengan pemberian perlakuan ekstrak biji pinang 40 g.l-1 air sebesar 60,00\%. Hal ini diduga karena kemampuan pestisida nabati terhadap hama ulat jengkal relatif sama, sehingga memiliki respon yang sama dalam membunuh ulat jengkal.

Senyawa arekolin yang terkandung dalam biji pinang masuk ke dalam tubuh ulat jengkal sebagai racun kontak dan racun perut (Eri, 2014). Senyawa arekolin sebagai racun kontak masuk ke tubuh ulat jengkal melalui lubang-lubang alami, setelah masuk ke dalam tubuh ulat jengkal senyawa arekolin bekerja sebagai racun saraf yang mengganggu perilaku serta menghambat reseptor perasa pada daerah mulut sehingga terjadi kerusakan saraf pada mulut akibatnya ulat tidak dapat melakukan aktifitas makan dan lama kelamaan ulat jengkal akan mati. Menurut Isroj (2008) bahwa perlakuan pestisida nabati ekstrak biji buah pinang mempunyai potensi sebagai racun kontak yang berspektrum luas, sehingga ulat yang memakan racun akan mati kelaparan karena tidak bisa melakukan aktifitas makan akibat kelumpuhan sistem saraf mulut.

Senyawa arekolin masuk ke dalam tubuh ulat jengkal selain sebagai racun kontak juga sebagai racun perut. Senyawa arekolin sebagai racun perut masuk ke dalam tubuh ulat jengkal melalui proses makan dan setelah masuk ke dalam tubuh ulat jengkal bekerja sebagai racun saraf yang menyebabkan pencernaan terganggu karena senyawa ini mempengaruhi aktifitas metabolisme sehingga menyebabkan terjadinya penurunan aktifitas gerak atau kelumpuhan dan akhirnya secara perlahan-lahan ulat akan mati. Hal ini sesuai dengan pendapat Nurtiati et al. (2001) menyatakan bahwa efek dari racun perut yaitu menurunnya aktifitas makan secara perlahanlahan, menghambat kontraksi usus sehingga proses pencernaan makanan tidak dapat berlangsung yang akhirnya akan menyebabkan kematian pada serangga uji. Hal ini didukung juga oleh Nismah et al. (2011) yang mengemukakan bahwa senyawa toksik yang masuk ke dalam tubuh serangga akan mempengaruhi metabolisme dalam tubuhnya. Proses metabolisme tersebut membutuhkan energi, semakin banyak senyawa racun yang masuk ke dalam tubuh ulat maka semakin besar energi yang dibutuhkan untuk menetralisis senyawa racun tersebut sehingga ulat akan kekurangan energi dan akhirnya mati.

\section{KESIMPULAN DAN SARAN}

\section{Kesimpulan}

Uji beberapa konsentrasi ekstrak biji pinang (Areca catechu L.) terhadap ulat jengkal pada tanaman kedelai diperoleh kesimpulan bahwa perlakuan konsentrasi 80 g.l-1 air merupakan konsentrasi yang efektif untuk mengendalikan hama ulat jengkal dimana pada konsentrasi ini dapat menyebabkan mortalitas total sebesar $87,50 \%$ 
dengan awal kematian 14 jam setelah aplikasi dan LT50 pada jam ke 29,25 setelah aplikasi.

\section{Saran}

Berdasarkan hasil penelitian yang telah dilakukan pada uji beberapa konsentrasi ekstrak biji pinang (Areca catechu L.) terhadap ulat jengkal disarankan menggunakan konsentrasi 80 g.l-1 air untuk mengendalikan ulat jengkal, karena dapat menyebabkan mortalitas total sebesar $87,50 \%$.

\section{DAFTAR PUSTAKA}

Ardiansyah, Wiranto, dan E. Mahajoeno. 2001. Toksisitas Ekstrak Daun Mimba (Azadirachta indica A. juss) pada Siput Murbei (Pomacea canaliculata) Skripsi (Tidak dipublikasikan). Universitas Negeri Surakata, Surakarta.

Dadang dan D. Prijono. 2008. Insektisida Nabati: Prinsip, Pemanfaatan dan Pengembangan. Departemen Proteksi Tanaman Institut Pertanian Bogor, Bogor.

Dewi, A. Y. M. 2017. Uji Beberapa Konsentrasi Tepung Biji Pinang (Areca catechu L) Terhadap Mortalitas Larva Penggerek Tongkol Jangung Manis (Helicoverpa armigera Hubner). Skripsi (Tidak dipublikasikan). Universitas Riau, Pekanbaru

Dono DN, I Rianingrum, Herawaty, E Suryanto \& Zuprizal. 2005. Penggunaan jahe merah (Zingiber officinale roscoe) dalam ransum untuk meningkatkan kualitas fisik daging ayam broiler. Prosiding Seminar AINI V. Malang 10 Agustus 2005

Eri. 2014. Uji Beberapa Konsentrasi Biji Pinang (Areca catechu) untuk Mengendalikan Hama Ulat Grayak (Spodoptera litura F.) pada Tanaman Sawi (Brassica juncea L.) Skripsi (Tidak dipublikasikan). Universitas Riau, Pekanbaru.

Gassa A., Sulaeha dan Y. Siswati. 2008. Uji keefektifan ekstrak buah pinang (Areca catechu L.) terhadap tingkat mortalitas jentik nyamuk Culex $s p$. (Diptera:Culicidae). Disampaikan pada Seminar Ilmiah dan Pertemuan Tahunan PEI XIX Komisaris Daerah Sulawesi Selatan. 5 Novemver 2008.
Isroj, 2008. Budidaya tanaman pinang. http://www.plant.com. Diakses pada 5 Agustus 2018.

Marwoto dan Suharsono, 2008. Strategi dan Komponen Teknologi Pengendalia Ulat Grayak (Spodoptera litura Fabricius) pada Tanaman Kedelai. Jurnal Litbang Pertanian, 27(4): 132133.

Mulyana. 2002. Ekstraksi Senyawa Aktif Alkaloid, Kuinon dan Saponin dari Tumbuhan Kecubung Sebagai Larvasida dan Insektisida terhadap Aedes agypti. Skripsi (Tidak dipublikasikan). Institut Pertanian Bogor, Bogor.

Nismah, N., Utami dan G. D. Pratami. 2011. Isolasi Senyawa Flavonoid dari Ekstrak air serbuk daun gamal (Gliricidia maculata) dan uji toksisitas terhadap hama kutu putih pepaya (Paracoccus marginatus). Pusat Penelitian dan Pengembangan Tanaman. Disampaikan pada Seminar Nasional Perhimpunan Entomologi Indonesia Cabang Bandung. 10-12 Februari 2011, Bandung.

Nursal E., P.S. Sudharto dan R. Desmier de chenon. 1997. Pengaruh Konsentrasi Ekstrak Bahan Pestisida Nabati terhadap Hama. Balai Penelitian Tanaman Obat, Bogor.

Nurtiati, Hamidah dan T. Widya. 2001. Pemanfaatan Bioinsektisida Ekstrak Daun Azadirachta indica A. Juss. sebagai Pengendali Hayati Ulat Daun Kubis Plutella Xylostella L., Jurnal Matematika dan Ilmu Pengetahuan Alam, 6 (1): 55-62.

Pracaya. 2007. Hama dan Penyakit Tanaman. Penebar Swadaya, Jakarta.

Prijono, D. 2002. Pengujian Keefektifan Campuran Insektisida: Pedoman bagi Pelaksanaan Pengujian Efikasi untuk Pendaftaran Pestisida. Institut Pertanian Bogor, Bogor.

Sari, M. 2013. Uji Efektivitas Beberapa Insektisida Nabati untuk Mengendalikan Ulat Grayak (Spodopera litura f.) (lepidoptera: noctuidae) di Laboratorium. Skripsi (Tidak dipublikasikan). Universitas Riau, Pekanbaru. 
Sastrodihardjo. 1984. Pengantar Entomologi Terapan. Institut Teknologi Bandung, Bandung. 